 \\ z Filologii Polskiej i Słowiańskiej
}

DOI: $10.11649 /$ sfps.2017.002

\author{
Zuzanna Krótki \\ (Katowice)
}

\section{Nazwy marzeń sennych w historii języka polskiego}

Szkody sen marny przynosi, Dary z nieba dobry wnosi, Zły sen złych spraw złym jest sprawcą, Dobry dobrych jest spraw dawcą

Stanisław Poklatecki

Sny od wieków fascynowały ludzkość i mimo ogromnego postępu studiów psychologicznych prawda o tym, co kryje się za plątaniną fragmentarycznych obrazów, nadal nie została odkryta. Starożytni Egipcjanie wierzyli, że sny mają siłę proroczą, Grecy uważali je za znak od bogów, umożliwiający nawiązanie dialogu ze zmarłymi, natomiast myśliciele chrześcijańscy (zwłaszcza żyjący w trzech pierwszych wiekach po Chrystusie) rozpatrywali sny w kategoriach objawienia (Cielo, 1917, ss. 30-52; Delaney, 2000, ss. 22-58).

Celem artykułu jest analiza dawnych nazw marzeń sennych, zarówno tych pozytywnych, jak i negatywnych. Pojęcie marzenie senne rozumiem jako 'to co się śni człowiekowi śpiącemu, obraz widziany w czasie spania' (USJP, 2003, hasło sen). Zebrany ze wszystkich źródeł leksykograficznych rejestrujących dawne

This is an Open Access article distributed under the terms of the Creative Commons Attribution 3.0 PL License (creativecommons.org/licenses/by/3.0/pl/), which permits redistribution, commercial and non-commercial, provided that the article is properly cited. (c) The Author(s) 2017.

Publisher: Institute of Slavic Studies, Polish Academy of Sciences

[Wydawca: Instytut Slawistyki Polskiej Akademii Nauk] 
słownictwo materiał nie jest jednorodny, niektóre jednostki charakteryzowały bowiem zarówno demony, przynoszące koszmary, jak i same niepożądane sny, inne stanowiły nazwę snu - czynności fizjologicznej oraz snu - marzenia sennego. Mimo że zakres prowadzonych badań wydaje się mocno sprecyzowany i zawężony (marzenie senne 'to, co się śni'), podczas analiz niejednokrotnie nie da się pominąć sensów niewiązanych z sennymi wyobrażeniami. Treści te traktowała będę jednak jako poboczne, gdyż zostały one dobrze opracowane w publikacjach Renaty Dźwigoł (2004), Janiny Cherek (1976), Wandy Budziszewskiej (1991), Wandy Drozdowskiej (1962) oraz Stanisławy Niebrzegowskiej (1996).

W badaniach wzięłam pod uwagę różne typy danych.

1. Dane leksykograficzne - na temat znaczeń wyrazów związanych z marzeniami sennymi, ich etymologię oraz derywaty słowotwórcze, zgromadzone na podstawie słowników rejestrujących dawną polszczyznę, tj. SStp (1966-2000), SXVI (1966), SWil (1861), SW, SD (1958-1969).

2. Dane tekstowe - wyimki ujęte w poszczególnych leksykonach oraz fragmenty dawnych traktatów dotyczących snów.

3. Informacje kulturowe ${ }^{1}$, niektóre zwyczaje i wierzenia opisane $\mathrm{w}$ pracach etnograficznych.

Artykuł podzielony został na trzy podrozdziały: 1. Jednostki o rdzeniu sen-/śn-; 2. Jednostki o rdzeniu mor-/mar-/marz-; 3. Jednostki o rdzeniu widz-. Podczas dokonywania wstępnych analiz okazało się bowiem, że wszystkie dawne nazwy marzeń sennych koncentrowały się właśnie wokół przywołanych członów.

\section{Jednostki o rdzeniu sen-/śn-}

Leksem sen wywodzi się od psł. rzeczownika *szpnz 'sen' (SBr, 1927), utworzonego na bazie czasownika *søpati, søp'o 'spać' (SBor, 2005; SBr, 1927). Przywołana postać derywatu utrzymywała się bardzo krótko, już w prasłowiańszczyźnie doszło bowiem do redukcji grupy dwuspółgłoskowej

1 Informacje kulturowe rozumiem jako „nieoparte na doświadczeniu zmysłowym wyobrażenia i przekonania ludzi, dotyczące przedmiotów i zjawisk rzeczywistości, w tym zwłaszcza przekonania jawnie wierzeniowe (...)" (Bartmiński \& Niebrzegowska-Bartmińska, 2008, s. 67). 
-pn-, w wyniku czego prasłowiańską nazwą snu stała się postać * ${ }^{*}$ šn (DługoszKurczabowa \& Dubisz, 2006, s. 160).

Analizowane jednostki (sen, ${ }^{*}$ søpati, søp' $Q$, ${ }^{*}$ søpnz, ${ }^{*}$ sønz) spokrewnione były z praindoeuropejskim rzeczownikiem heteroklitycznym *suépōr 'sen' (SBor, 2005), od którego powstały m.in. łaciński somnus 'sen', litewski sãpnas 'sen', łotewski sapns/sapnis 'sen', staroindyjski svápna 'spanie, sen' (SBor, 2005), także niemiecki Schlaf 'sen', francuskie sommeil 'sen', włoski sonno 'sen', rumuński somn, szwedzki somn, bułgarski сън. Zdaniem Alexandra Borbély'ego pie. pierwiastek suep-, pokrewny pie. elementowi -slu- 'wiotki słaby, bezbronny' (obecny m.in. w niem. Schlummer 'drzemka i angielskim to slumber 'zdrzemnąć się') znaczył pierwotnie tyle, co 'zwiotczeć, stać się słabym, bezsilnym' (Borbély, 1990, s. 13). W przywołanej treści badacz upatruje związku z sensem 'śmierć', który bez wątpienia w większości języków świata stanowi znaczenie metaforyczne wyrazu sen (oraz jednostek jemu pokrewnych) por. np. niem. entschlafen 'zasnąć na wieki' czy polski zwrot spać snem wiecznym² (USJP, 2003).

Mimo że już w najdawniejszej polszczyźnie sen odgrywał nieraz rolę eufemizmu śmierci, takie użycia nie są przedmiotem niniejszej refleksji. Za kluczowe zadanie podejmowanych badań uznałam bowiem próbę zgromadzenia jak najpełniejszego zbioru nazw marzeń sennych. Pragnę zatem na początku zbadać, od kiedy leksem sen oznacza 'to, co się śni'.

Co ciekawe, mimo że w staropolskich tekstach badany wyraz nie został poświadczony, mamy podstawy do tego, by przypuszczać, że już w tym czasie funkcjonował on w znaczeniu 'marzenia senne'. Na obecność zasygnalizowanego sensu wskazuje m.in. derywat leksemu sen - sennik, który od XV do końca XVIII wieku nazywał 'wykładacza, objaśniacza marzeń sennych' (SStp, 1966-2000). W sposób eksplicytny analizowane znaczenie nie zostało jednak odnotowane w treści wyrazu sen.

Pojawiało się ono natomiast w niezwykle precyzyjnym wywodzie Stanisława Poklateckiego (eksjezuity, żyjącego w XVI wieku), zatytułowanym Snow dobrych obronę i szkodliwych przestrogę z potrzebnymi naukami rodzajewi ludzkiemu:

sen ma obrazy w sobie rzeczy przyszłych, jest abo z poduszenia szatańskiego, abo z rozmaitego postanowienia i umiarkowania ciała i sieł a skłonność jego, abo $\mathrm{z}$ wyrażonych $\mathrm{w}$ rozumie na jawie spraw a ich potężnym a usilnym obmyśleniu abo świętością niebieską za dar Boży bywa sen dany (Poklatecki, 1595/2011, s. 58).

2 Zob. też „Sen śmierci bratem” Kulig. Her. 67 (SL, 1807-1814), „O miła śmierci zmysłów, złości zapomnienie, śnie, ty dajesz w pracach odetchnienie” Zab. 14, 119 (SL, 1807-1814). 
Według teologa marzenia senne, czyli sny zorganizowane przez treść głównie proroczą, hermeneutyczną, niezrozumiałą, domagające się eksplikacji przez wykwalifikowanych interpretatorów - mają rozmaite pochodzenie. Mogą być zsyłane przez Boga - wówczas są to sny dotyczące spraw „wysokich, poważnych, zacnych" (przykładem mogą być marzenia senne Abimelecha, Labana czy Józefa Patriarchy [Poklatecki, 1595/2011, ss. 68-69]) - lub szatana, który daje plugawe, sprośne i okrutne sny ludziom bogobojnym, szlachetnym i czystym, „aby ich zeszpecić i oszkaradzić” (Poklatecki, 1595/2011, ss. 66-67). Poklatecki nie wyklucza również możliwości powstania snu będącego wynikiem pracy ludzkiej świadomości, zdeterminowanej realnymi wydarzeniami.

Zauważyć można, że w najpopularniejszym szesnastowiecznym traktacie o snach leksem sen pełni funkcję nazwy wszystkich marzeń sennych: zarówno tych profetycznych, jak i grzesznych, także koszmarów. Należy ponadto dodać, że w tekście tegoż traktatu nie pojawia się inne określenie 'tego, co się śni'. $\mathrm{Z}$ bardzo podobną sytuacją spotykamy się, badając dzieła takich renesansowych myślicieli, jak np. Mikołaj Rej, Marcin Bielski czy Piotr Skarga. Mimo że w pismach wymienionych „ludzi pióra” nierzadkie wydają się połączenia sen a mara, najpopularniejszą nazwą marzenia sennego jest właśnie sen.

W siedemnastowiecznym Thezaurusie Grzegorza Knapiusza badany leksem zawiera natomiast dwa znaczenia: 1. 'sen, spanie, spik, dormitio [...]'. Kn 987 (SXVII, 1999-2014) oraz 2. 'sen to co się śni, somnium' [...]. Kn 987 (SXVII, 1999-2014). Zauważyć można, że już w zasygnalizowanym okresie odróżniano sens 'senne wizje' od treści 'stan służący regeneracji sił witalnych'. Poświadczona została również pierwsza nazwa somnologii, tj. senna nauka („Senna nauka, do snów wykładania służąca [...]. Kn 987, SXVII, 1999-2014), odnotowano ponadto liczne, niezwykle szczegółowe opisy marzeń sennych, np.

Aż mi sen wdzięczny te przysługę sprawił, żem swą dziewczynę całował bez trwogi i w jej gładkości myśli moje bawił. Morsz.AUtw Kuk (SXVII, 1999-2014);

Brata Dauletem: $z$ nie zwano Xifilem, porwie się w rzeczy poprawując suknie, wychodzi chyżo i ramiona ściśnie, a łza mu po łzie prądem z oczu pryśnie. Potym sam z sobą: Przebóg sen czy czary, wzdyć Xifil umarł? PotSyl 104 (SXVII, 1999-2014).

W SL wyraz sen objaśniony został w bardzo podobny sposób. W leksykonie tym zarejestrowano nawet fragmenty, w których analizowany leksem oznacza zarówno 'spanie', jak i 'to, co się śni, marzy, widowisko senne' (SL, 1807-1814), np. 


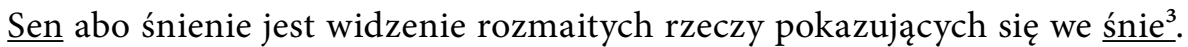
Sak. Probl. 235 (SL, 1807-1814);

Starcowie wasi będą we śnie sny miewać. 1 Leop. Act. 2, 17 (SL, 1807-1814).

$\mathrm{Z}$ innych osiemnastowiecznych fragmentów wynika również, że polscy myśliciele doby oświecenia najczęściej przyczyn marzeń sennych upatrywali w życiu codziennym, a znaczenia 'dar od Boga' lub 'zemsta demona' były dość rzadkie $^{4}$ (np. „Sny przychodzą albo z tych rzeczy, które człowiek widzi, słyszy, albo z tych, o których myśli”. Biał. Post. 121, SL, 1807-1814; „Sny są w dzień wymalowane obrazy, cieniem nocnym zepsowane" Past. Fid 48, SL, 1807-1814). Pojawiły się także nowe nazwy osób zajmujących się wyjaśnianiem snów. Poza staropolskim sennik pod koniec doby średniopolskiej stosowano także takie określenia jak: śniarz, snowidz, snownik, snowieszczek, zmyślacz snów, snów wykładacz. Pierwsza z wymienionych jednostek (śniarz) w niektórych kontekstach oznaczała 'proroka', któremu się „,często co znacznego śni, albo który sny swe rad powiada" (SL, 1807-1814). Częstsze było jednak znaczenie 'snów wykładacz’ (SL, 1807-1814). Pozostałe leksemy charakteryzowały wyłącznie osobę zajmującą się interpretacją snów.

W kolejnym stuleciu znaczenia analizowanych nazw osobowych uległy pewnej modyfikacji semantycznej. Wyraz sennik coraz częściej wiązano bowiem z analizą snów ('wykład snów', SWil, 1861) lub z książką ułatwiającą objaśnienia marzeń sennych (np. „Miałem sennik, który mi ksiądz pleban odebrał, mówiąc, iż to jest książka zakazana”; „Pieśni boży senniku, prawda w tobie i z ciebie”, SWil, 1861; Zob. Niebrzegowska, 1996). Treści typu 'ten, któremu się coś znaczącego śni' lub 'interpretator snów' jawiły się natomiast jako przestarzałe. $\mathrm{Z}$ nieco inną sytuacją spotykamy się podczas analiz pozostałych nazw osób tłumaczących marzenia senne. Leksemy śniarz, snownik czy snowidz do końca swej historii (do początku XX wieku) oznaczały bowiem wyłącznie 'tłumacza snów', natomiast jednostki typu snowieszczek oraz zmyślacz snów stosowano tylko w odniesieniu do szarlatanów (Krótki, 2015, s. 180).

Nie zmieniła się natomiast treść wyrazu sen. Zarówno w XIX, jak i w XX wieku leksem ten oznaczał 'spanie, stan śpiącego' (SWil, 1861; SW; SD, 1958-1969) oraz 'to, co się śni, marzenie senne, widzenie śpiącego' (SWil,

3 Wszystkie podkreślenia pochodzą od autorki.

${ }^{4}$ Jeśli w dawnych tekstach mowa była o snach zsyłanych przez złe dusze, stosowano inne jednostki. Temat ten zostanie jeszcze poruszony. 
1861; SW; SD, 1958-1969). Da się jednak odczuć, że w niektórych kontekstach badana jednostka stanowiła również nazwę urojenia (lub po prostu marzenia), np. „Komu by się wszystkie sny Alkoranu podobały?” (SWil, 1861), „Mimo snami uciec z życia” Wysp. Wesp. 49 (SD, 1958-1969). Takich użyć było niewiele, gdyż od połowy XIX wieku zasygnalizowane treści przypisywano leksemowi marzenie.

\section{Jednostki o rdzeniu mor-/mar-/marz-}

Najbardziej rozbudowaną grupę nazw marzeń sennych tworzyły jednostki oparte o pie. rdzeń * mer-, który według Wiesława Borysia i Andrzeja Bańkowskiego mieścił znaczenie 'błyszczeć, lśnić, migotać' (SBor, 2005; SBań, 2000). Pierwiastek ten obecny był w psł. rzeczowniku ${ }^{\star}$ mara 'widziadło, przywidzenie, urojenie', także w psł. czasowniku ${ }^{*}$ mbrěti ${ }^{*}$ mbriti 'migotać, majaczyć, być ledwo widocznym ${ }^{\text {'5 }}$ (SBor, 2005; SBań, 2000). Inne znaczenie tego pie. trzonu wskazała Wanda Budziszewska, przywołując psł. derywat ${ }^{*}$ mora istota mityczna, dusząca ludzi w czasie snu'. Według badaczki analizowana pie. podstawa musiała wnosić znaczenie 'cisnąć, tłoczyć' (Budziszewska, 1991, s. 17). Przypuszczać zatem można, że pie. ${ }^{\star}$ mer- był polisemiczny, co potwierdza również stanowisko Olega Nikołajewicza Trubaczowa. Przyjęcie zasygnalizowanej hipotezy skutkuje uznaniem związku mary i mory za dość odległy (Dźwigoł, 2004, s. 58).

W staro- i średniopolskich tekstach pierwsza z wymienionych jednostek, jeśli odnosiła się do sił nadprzyrodzonych, nazywała najczęściej pojawiającego się w snach okrutnego demona. Zdarzały się co prawda użycia, w których mara charakteryzowała również ducha sprzyjającego ${ }^{6}$ (np. „Coż jest przebog, duch czy mara? Dziwnać jakaś Boża stwora” M Wilk. Hist. K4, K4, SXVI, 1966), niemniej było ich naprawdę niewiele.

Znacznie liczniejsze od tych użyć implikujących postaci nadnaturalne wydają się poświadczenia wiążące badany leksem z tym, „co śpiącemu się marzy, co śpiący przez ten sen widzieć mniema” (SL, 1807-1814) (np. „Najpróżniejsza na marze snów dalszych zakładać nadzieje”. Boh. Zajom. 220, SL, 1807-1814) lub po prostu z 'urojeniem', np. „Widzisz moja miła żono, w rze-

5 Por też. rosyjskie mar 'suche, migotliwe powietrze w upalny dzień, tzw. „sucha mgła”' (SBań, 2000).

${ }^{6}$ W przypadku leksemu mora takiego znaczenia nie poświadczono. 
czy samej, że wszystko sen i mara, cokolwiek jest na świecie” Wys. Kas. 14 (SXVI, 1966). Zaskakujące jest więc to, że u progu doby nowopolskiej mara staje się coraz bliższym synonimem mory lub zmory, frekwencyjnie częściej oznacza bowiem 'widzenie senne przerażające, senne widziadło' (SWil, 1861) lub 'widziadło, postać znikomą, cień postaci, zjawisko nadnaturalne, postać nieboszczyka' (SWil, 1861). Przyczyną wspomnianego zjawiska było zapewne podobne brzmienie wymienionych wyrazów.

Leksem mora, notowany od XVI wieku, na początku swej historii wiązany był bowiem wyłącznie z wierzeniami ludowymi (wręcz pogańskimi). Niektórzy etnografowie przyjmują nawet, że nazwa ta do Polski przyszła za sprawą języka niemieckiego, w którym Mahr stanowił określenie germańskiego bóstwa ${ }^{7}$ (Baranowski, 1981, s. 70). Nie dziwi zatem fakt, że analizowana jednostka na gruncie polskim pierwotnie charakteryzowała wyłącznie niebezpieczne 'białe widziadło’ (SBor, 2005), wysysające krew z ciała śpiącego człowieka lub duszące go w czasie snu, np.

Znamię jest zbytniej krwie $\mathrm{w}$ ciele, $\mathrm{z}$ której przychodzi mara, to jest duszenie w spaniu" Glab. Gad L6 v (SXVI, 1966);

Mora też jest niemoc (po łacinie zową incubus) gdy się człowieku widzi we spaniu, jakoby go co przyległo, tak iż się ruszyć nie może, kto chce dławienia ujść nie legaj na wznak. Glab. Gad D8 (SXVI, 1966).

Na uwagę zasługuje zwłaszcza drugi cytat, na podstawie którego wnioskować można, że już w XVI wieku leksem mora mógł być stosowany w znaczeniu 'koszmar'. Do takiego przesunięcia doszło na skutek analogii: duszące senne widziadło - sen wywołujący duszności lub ucisk w krtani. Chociaż jeszcze z osiemnasto- i dziewiętnastowiecznych ${ }^{8}$ tekstów (SL, 1807-1814; SWil, 1861) wyczytać można, że „Duszenie nocne zbytniej krwi prości ludzie duchowi przypisują, którego morą zową" Syr. 740, et 100, et 122 (SL, 1807-1814), w połowie doby średniopolskiej coraz częstsze staje się znacznie 'dreszcze, ciarki, mrowie, duszności', np.

Mory mię przechodzą. Chrość. Ow. 3 (SL, 1807-1814);

Zaraźliwa choroba i straszna, nad którą nie widziałem straszniejszej; jeszcze mory biorą, gdy wspomnę. Przyp. Luz 165 (SL, 1807-1814).

7 Aleksander Brückner wyraża wątpliwość co do tego związku.

${ }^{8}$ Nawet u Kolberga czytamy, że „(...) mora kładzie się na człowieku, język swój wsadzi w jego gębę i wszystkie śliny mu wycycka, że ino jak wiór mu w gardle ostanie”(Kolberg, 1962, s. 42) 
Analizowana treść zaczyna dominować na początku XX wieku (por. mora 'cierpienie, choroba', SW), a pod koniec tego stulecia mora nie jest już wiązana z marzeniami sennymi, tylko z objawami gorączki (z kolei w późniejszym okresie nie jest rejestrowana). Natomiast mara od tego momentu pełni funkcję nazwy „sennego widowiska”.

Budzi również zaskoczenie to, że na początku XVII wieku, kiedy to wzrasta poziom nieufności względem wszelkiego rodzaju zabobonności (Kowalewska, 2009, s. 271), poświadczony zostaje nowy wyraz, oznaczający demona dręczącego ludzi podczas snu. Jest nim leksem zmora, który (w odróżnieniu od poprzednich jednostek) uznaje się za wyłącznie polską formację, pochodną od zmorzyć (Budziszewska, 1991, s 18) lub od zmarly (Baranowski 1981, s. 66). W wyobrażeniach ludowych dawne, słowiańskie mory były bowiem istotami zbliżonymi do upiorów, Szymon Syreniusz stwierdził nawet, że „duszenie nocne zbytniej krwi sercu prości ludzie u nas duchowi przypisywali, który zmorą zwą" (Syreński, 1613, s. 37). Użycie czasu przeszłego w cytowanym wyimku jest znaczące, pozwala bowiem przypuszczać, że leksem zmora znacznie wcześniej funkcjonował w polszczyźnie. Potwierdzają to również badania przeprowadzone przez Renatę Dźwigoł (2004, s. 58). Dowiodły one, że wyraz zmora w znaczeniu 'duch niepozwalający spać' pojawiał się w już w staropolskich gwarach.

Z ogólnopolskich tekstów z początku XVIII wieku dowiadujemy się z kolei, że zmora nazywano przede wszystkim 'mrowie' (np. „Wspomniawszy na to przez mię idzie zmora” Pot. Arg. 758, SL, 1807-1814; „zląkłem się, aż przez mię szła zmora". Morsz. 307, SL, 1807-1814), natomiast treść 'upiór, strzygoń' plasowała się na drugim planie (SL, 1807-1814).

Najprawdopodobniej jednak w niezapisanych tekstach gwarowych (które, jak wiadomo, przekazywane oralnie, rządzą się swoimi prawami) zmora nadal znaczyła demona, z tym że utożsamiano ją najczęściej z czarownicą (zob. gwar. „jak czarownico siercowato jest, tu głowę trzyma, a tam widzi człowieka”, Drozdowska, 1962, s. 125). Wierzono bowiem, że istota ta pod postacią kota, myszy, szczura, ryby, żaby lub łasicy nawiedza śpiących: dusi ich albo wysysa krew z ich ciała (Baranowski, 1981, ss. 67, 70).

Referowany mit musiał być dobrze znany i często powtarzany wśród użytkowników języka doby średniopolskiej, jako że w kolejnym stuleciu (w XIX wieku) dominantą semantyczną leksemu zmora był właśnie sens 'duch napastujący konie i ludzi śpiących' (SW), np. „Jeszcze nim dziatwę, jak zmorą straszyła” (SWil, 1861; SW). Z przywołanego znaczenia na skutek 
derywacji semantycznej zrodziła się na początku XX wieku treść 'koszmar', czyli ciężki sen $z$ halucynacjami, bardzo przykrymi marzeniami sennymi, wywołujący nieraz uczucie gniecenia, duszenia w klatce piersiowej, np. „Co chwilę budził się, gdyż straszyły go zmory” Brzoza Dzieci 148 (SD, 1958-1969). Powyższy odcień semantyczny uznaje się obecnie za sens prototypowy zmory (USJP, 2003).

Leksemy mara, mora i zmora nie były jednak jedynymi dawnymi, opartymi o pie. pierwiastek ${ }^{*}$ mer- nazwami marzeń sennych. Jak już pisałam, rdzeń ten przyczynił się bowiem również do ufundowania psł. czasownika *mbrěti/* mbriti 'migotać, majaczyć, być ledwo widocznym', od którego z kolei wygenerowana została postać *mariti 'powodować, że się coś ukazuje, pojawia, roi' (SBor, 2005). Analizowany wyraz na gruncie polskim przybrał natomiast (już w XV wieku) formę marzyć, a jego znaczenie uległo subtelnej modyfikacji. Nie można jednak wykluczyć innej drogi powstania badanej formacji - od psł. ${ }^{*}$ mara (SBor, 2005).

Niezależnie jednak od tego, którą z hipotez dotyczących genezy czasownika marzyć przyjmiemy, najistotniejsze wydaje się to, że badany leksem już na początku swej historii zawierał bardzo bliską współczesnej strukturze semantycznej treść, tj. 'rozmyślać o rzeczach przyjemnych, najczęściej nierealnych, fantazjować; stwarzać w wyobraźni postać czegoś, bardzo czegoś pragnąć, śnić, roić we śnie", np. „Alje Żydowie marzą (somniant), iżby ten psalm był pisan w personie Eliaszowej" Rozm. 416 (SStp, 1966-2000). Od tegoż czasownika wygenerowane zostało gerundium marzenie, które, jak się wydaje, na początku doby średniopolskiej wiązane było wyłącznie ze złym snem. Mam również wrażenie, że badany wyraz zawierał w tym czasie znaczenie podobne do późniejszej mory tj. 'to, co dusi we śnie', np.

Czym marzenie i gniecenie we śnie odpędzać? Sien. Lek. 57 (SXVI, 1966);

Czym marzenie we śnie, szukaj gniecenie Sien. Lek. S. 2, 57 (SXVI, 1966).

Ciekawe jest to, że w tekstach osiemnastowiecznych czasowniki marzyć oraz marzyć się wiązane były głównie ze złym snem. W SL odnotowano bowiem zaledwie jeden fragment, na podstawie którego można wnioskować, że leksem marzyć się oznaczał 'rozmyślanie o rzeczach przyjemnych' lub 'fantazjowanie’ (tj. „On sam nie wie, co mu w głowie się marzy” Teat. 35, c, 61, SL,

9 Z podobną sytuacją mamy do czynienia w przypadku słowackiego marit' sa 'wydawać się, pojawiać się, śnić się’ oraz ukraińskiego marýty 'marzyć, roić we śnie’. 
1807-1814). Mamy zatem podstawy, by przypuszczać, że jeszcze w XVIII wieku słowo marzenie znaczyło wyłącznie 'koszmar', na co wskazuje m.in. fragment: „Długom został bez władzy jak kamień nieczuły, marzenia się okropne tylko w oczach snuły” Teatr. 44. D, 19 (SL, 1807-1814). Sens 'dumanie, rojenie myśli pełne łudzących, ponętnych obrazów’ zwerbalizowany został natomiast dopiero w SWil ([1861] z tym że ujęty został jako drugie znaczenie) ${ }^{10}$. Do utrwalenia kolokacji marzenia senne, oznaczającej 'treść uświadamiającą się podczas snu' (SW), doszło na początku XX wieku. Z kolei w połowie tego stulecia przywołane wyrażenie wiązano również z przyjemnym i pięknym snem, np. „Luby wiek minął jak senne marzenie" Ziel. G. Poezje 223 (SD, 1958-1969).

Na początku XX wieku coraz bardziej popularnym określeniem złego snu staje się pochodzący z francuszczyzny leksem koszmar. Wyraz ten (podobnie do analizowanych wcześniej jednostek) wywodzi się od pie. pierwiastka * mer-, który tworzył również inne, ogólnoeuropejskie nazwy nieprzyjemnych marzeń sennych, tj. np. niemieckie Mahr, angielskie night-mare, szwedzkie matt-mara czy holenderskie nacht-merrie (SBań, 2000). Nasuwa się zatem pytanie, dlaczego zapożyczony z języka francuskiego koszmar wyparł wcześniejsze nazwy marzeń sennych. Przypuszczać można, że przyczyną tego zjawiska był wzrost zainteresowania psychoanalizą, jaki obserwujemy u progu XX wieku. W tym czasie do Polski docierają tłumaczenia pism Zygmunta Freuda przygotowane przez Ludwika Jekelsa, Maurycego Bornsztajna, Gustawa Bychowskiego, Salomeę Kepnerównę oraz Eugenię Sokolnicką. Wymienieni badacze na początku pracowali z pionierem psychoanalizy, później przenieśli się do Francji, by tam móc prowadzić swoje własne badania (Ostrowska, 2005, s. 52). Najprawdopodobniej dzięki publikacjom tych właśnie osób polszczyzna adaptowała pochodzący z języka francuskiego leksem cauchemar, który już na początku XX wieku był niezwykle „modnym” określeniem nieprzyjemnego snu.

Na uwagę zasługuje jednak to, że we wspomnianym okresie badana jednostka była dokładnym odwzorowaniem francuskiej słowoformy. W tekstach dwudziestowiecznych niemal bezwyjątkowo stosuje się formę koszemar (np. „Różne reminiscencje wieczorne, zlały się w jeden koszemar” Od., SW), natomiast koszmar stanowi w tym czasie niezwykle rzadki wariant fonetyczny analizowanego leksemu. Parę lat później przywołana postać leksykalna ulega

10 Andrzej Bańkowski pisze nawet, że „dopiero w marzycielskim wieku XIX szerzy się nowe znaczenie <obraz czegoś upragnionego, tworzony w wyobraźni>” (SBań, 2000). 
całkowitemu wyparciu na rzecz formy koszmar (np. „Przez dziesiątki lat w snach podgorączkowych wracał mi koszmar egzaminów” Krzywosz. Życie I, 10, SW), która, jak się wydaje, obecnie stanowi najbardziej prototypową nazwę nieprzyjemnego marzenia sennego (np. „Po całych nocach śniły mu się koszmary" [USJP, 2003])

\section{Leksemy o rdzeniu widz-}

Ostatnią grupę nazw marzeń sennych tworzyły jednostki powstałe na bazie czasownika widzieć, pokrewnego względem wiedzieć. O zasygnalizowanym związku pisano wiele (Brzozowska, 2009; Dancygier \& Sweetser, 2014), toteż nie będę powtarzała wniosków z przeprowadzonych analiz. W niniejszej refleksji ważniejsze są bowiem ramy czasowe, $w$ jakich funkcjonowały takie derywaty jak widzenie oraz widziadło.

Pierwsza z wymienionych jednostek (widzenie) w zależności od tła sytuacyjnego opisanego w tekście mogła pełnić funkcję nazwy czynności (wówczas oznaczała 'oglądanie', 'postrzeganie oczyma' lub 'sądową wizję lokalną'), nazwy środka czynności (tj. 'zmysł wzroku') lub nazwy obiektu (Kleszczowa, 1996, ss. 225-254). Jednak tylko ostatnia funkcja wiązała badany leksem z tematyką marzeń sennych. Widzenie (jako nazwa obiektu) obejmowało bowiem swym zasięgiem wszystko 'to, co się widzi', zatem zarówno obrazy otaczającego świata, jak i sny, także zjawy i objawienia, np.

Noccium fantasmata nocna widzenia obłudności, pokusy diabelskie (procul recedant somnia et noctium phantasmata). 144 R XXIII 307 (SStp, 1966-2000);

Przyszedł Bog w widzeniu (per somnium nocte) $<$ do $>$ Abimelech krola. BZ Gen 20, 3 (SStp, 1966-2000).

Zdecydowanie węższy był zakres użyć wyrazu widziadło (SStp, 1966-2000). Fakt ten nie powinien dziwić. Formant - $d \nmid o$ tworzył bowiem w dobie staropolskiej wyłącznie nazwy środków czynności (Kleszczowa, 1996, ss. 170-173). Widziadło (stp. widzidło) prymarnie oznaczało zatem 'to, co się widzi', natomiast sekundarnie (od XV wieku) 'nierealną postać, złudzenie wzroku, obecne nieraz w snach' (SStp, 1966-2000). Nasuwa się zatem pytanie, czy leksem ten mógł charakteryzować również senne obrazy. Na podstawie staro- i średniopolskich ułamków tekstowych nie sposób udzielić jednoznacznej odpowiedzi, tym bardziej że ani w piśmiennictwie dziewiętnastowiecznym, ani nawet w tekstach 
z połowy XX wieku treść 'marzenie senne' nie została poświadczona. Widziadło oznaczało co prawda w tym okresie 'rzecz potworną' lub 'marę' (por. 'kształt czego znikomy, przedmiot nieistniejący, który przez złudzenie zmysłów niby widziany', SWil, 1861), niemniej w tym czasie badanego leksemu nie można rozpatrywać w kategoriach synonimu snu.

Zaskakujące jest więc to, że we współczesnej polszczyźnie wyraz widziadło stosuje się często w odniesieniu do 'obrazu, który nam się przyśnił lub przywidział; widma, zjawy, przywidzenia, zjawiska' (USJP, 2003). Niewykluczone zatem, że analizowane znaczenie obecne było w treści jednostki widziadło wcześniej, z tym że nie zostało zarejestrowane w tekstach. Możliwa jest również inna droga rozwoju powyższego znaczenia - na skutek przeniesienia nazwy widziadło 'istota mityczna dręcząca podczas snu' na widziadło 'zły sen, koszmar'.

Nieco odmienną historię miał leksem widzenie. Od staropolszczyzny pełnił on bowiem funkcję nazwy tzw. snu przyszłościowego, czyli marzenia sennego obrazującego zmiany w aktualnie istniejącej sytuacji (Ostrowska, 2005, ss. 28-29). Cytowany sens utrzymywał się dość długo - jeszcze w tekstach osiemnasto- i dwudziestowiecznych widzeniem określano sny prorocze (widzenie „zjawisko, widziadło prorocze, ukazujące się postaci osoby jakiejś we śnie (...), SWil, 1861):

Śnie mój, ba nie sen, raczej cię widzeniem nazwę, prorockim, boskim obwieszczeniem". Past. Fid 311 (SL, 1807-1814);

Wyjawił im wszystko to widzenie, które miał w nocy przeszłej. Ustrz. Kruc. 1, 250 (SL, 1807-1814);

Kardynał, gdy mu się w nocy ś. Stanisław pokazał, natychmiast papieżowi widzenie swoje opowiada. Krom. 261 (SL, 1807-1814).

Analizowana treść powtarzana była jeszcze w SW (wraz z licznymi pochodzącymi z SL cytatami), z tym że uznana została (w tym leksykonie) za przestarzałą. Od połowy XX wieku natomiast znaczenie widzenia zbliża się do treści widziadła. Leksem ten wiązany jest bowiem przede wszystkim z 'przywidzeniem' lub z 'halucynacjąa' (np. „Miewa widzenia i ekstazy”. Bystr. Publ. 162, SD, 1958-1969).

Nie znaczy to jednak bynajmniej, że treść 'sen' została w tym czasie zapomniana (np. „Śpiąc krótko, ocknąłem się, i całe widzenie okazało się, że jest senne urojenie". Zabł. Pasterz 286, SD, 1958-1969), wprost przeciwnie, nadal stosowana jest kolokacja senne widzenie (USJP, 2003), którą rozumieć należy jako 'to, co widzimy w snach'. 


\section{Zakończenie}

Problematyka marzeń sennych to zagadnienie natury interdyscyplinarnej, w które zaangażowane są różne dyscypliny naukowe, przede wszystkim psychologia i psychoanaliza (Freud, 1982, 2000, 2010), filozofia (Kant, 1900), historia, etnografia, kulturoznawstwo, folklorystyka, a także lingwistyka. Wobec ogromu prac poświęconych snom zadanie, jakie sobie postawiłam, było skromne. Dotyczyło jedynie próby zakreślenia zbioru jednostek, które niegdyś charakteryzowały marzenia senne.

Przeprowadzone analizy pokazały, że nazwy marzeń sennych powstawały w oparciu o cztery sięgające swymi korzeniami języka praindoeuropejskiego obrazy, tj.: 1. obraz unicestwienia, śmierci, zagłady, 2. obraz czegoś błyszczącego, lśniącego, migotliwego, a w związku z tym ulotnego i nieuchwytnego, 3. obraz tego, co dusi, ciska, tłoczy, oraz 4. obraz tego, co się widzi, i jednocześnie tego, co się wie (o przyszłości).

Najliczniejszą grupę tworzyły jednostki sytuujące się w trzecim polu, przywołującym portrety czegoś, co dusi, ściska, wysysa krew. Najczęściej były to nazwy, które wpierw charakteryzowały mityczne postaci (tj. mara, mora, zmora). Fakt ten nie powinien dziwić, wszak w momencie, gdy tradycyjna wiedza ludowa nie znajduje wytłumaczenia dla wielu zjawisk zachodzących w przyrodzie, powstanie tych zjawisk przypisuje się postaciom nadprzyrodzonym - demonom. Jednostki sytuujące się w analizowanym kręgu najczęściej oznaczały obrazy senne, wywołujące nieprzyjemne doznania, jak np. uczucie przerażenia, rozpacz, wstrząśnięcie, także doznania fizyczne, typu ból, ucisk w klatce piersiowej, zduszenie w krtani. Obawiano się, że wyśnione, nocne widowiska powtórzą się na jawie, toteż między innymi dlatego zgłaszano się do interpretatorów snów.

Wszystkie wyrazy określające „tłumaczy marzeń sennych” generowane były natomiast na bazie rzeczownika sen. Wyraz ten od zawsze pełnił bowiem funkcję hiperonimu całej kategorii, nazywając zarówno pozytywne, jak i negatywne marzenia senne, także sny przyszłościowe.

Bardziej sprecyzowane znaczenie zawierały wyrazy utworzone od czasownika widzieć. Jednostki te w staropolszczyźnie najczęściej występowały w tekstach sakralnych, w których to oznaczały sny prorocze, dyktowane przez Boga. W późniejszych tekstach zdarzały się co prawda użycia sugerujące, że sprawcą widzenia lub widziadła może być również szatan, niemniej było ich niezwykle mało. Sądzono bowiem, że sny, w których można zobaczyć przyszłość, dostarczają podmiotowi śniącemu pewną wiedzę, będącą darem od Stwórcy. 
Z kolei w odniesieniu do snów ulotnych pierwotnie stosowano nazwy przywołujące obrazy tego, co błyszczy, migoce, świeci. Bardzo szybko jednak zasygnalizowane znaczenie zostało zapomniane, wyrazy te weszły bowiem na stałe do pola 3., przywołującego wizerunki „czegoś duszącego”.

Historia nazw marzeń sennych pokazuje, jak bardzo język zależny jest od rzeczywistości pozajęzykowej, w której został osadzony i spisany.

\section{Wykaz skrótów}

SBań - Bańkowskiego, A. (2000). Etymologiczny słownik języka polskiego. Warszawa: Wydawnictwo Naukowe PWN.

SBor - Boryś, W. (2005). Słownik etymologiczny języka polskiego. Kraków: Wydawnictwo Literackie.

$\mathrm{SBr} \quad$ - Brückner, A. (1927). Słownik etymologiczny języka polskiego. Warszawa: Krakowska Spółka Wydawnicza.

SD - Doroszewski, W., red. (1958-1969). Słownik jezzyka polskiego. Warszawa: PWN.

SL $\quad$ - Linde, B.S. (1807-1814). Słownik języka polskiego. Warszawa.

SStp - Urbańczyk, S., red. (1966-2000). Słownik staropolski. Warszawa-Wrocław-Kraków: IJP PAN.

SW - Karłowicz J., Kryński A., Niedźwiedzki W., red. (1900-27): Słownik języka polskiego, t. 1-8. Warszawa: Ossolineum.

SWil - Zdanowicz, A., Bohusz - Szyszka, M., red. (1861). Słownik języka polskiego. Wilno.

SXVI - Mayenowa, M. R., red. (1966). Słownik polszczyzny XVI wielu. Wrocław-Warszawa-Kraków: Ossolineum.

SXVII - Bańko, M., Bobrowski, I., Karpiński, A., Karpluk, M., Puzynina, J., Rzepka W.R., Siekarska K., red. (1999-2014). Elektroniczny słownik XVII i pierwszej połowy XVIII wieku, http://sxvii.pl/ [dostęp: 10.10.2015].

USJP - Dubisz, S. (2003): Uniwersalny słownik języka polskiego, Warszawa: Wydawnictwo Naukowe: PWN

\section{Bibliografia}

Baranowski B. (1981). W kręgu upiorów i wilkołaków. Łódź: Wydawnictwo Łódzkie.

Bartmiński, J., \& Niebrzegowska-Bartmińska, S. (2008). Miejsce informacji kulturowej w znaczeniu słowa i w rekonstrukcji językowego obrazu świata. W: G. Szwat-Gyłybowa, M. Bogusławska (Red.), Bunt tradycji tradycja buntu: Księga dedykowana Profesorowi 
Krzysztofowi Wrocławskiemu (ss. 65-77). Warszawa: Instytut Slawistyki Zachodniej i Południowej UW.

Borbély, A. (1990). Tajemnice snu (W. Szelenberger \& M. Szelenberger, Tłum.). Warszawa: Państwowe Wydawnictwo Naukowe.

Brzozowska, M. (2009). Etymologia a konotacja słowa:. Studia semantyczne. Lublin: Wydawnictwo Uniwersytetu Marii Curie-Skłodowskiej.

Budziszewska, W. (1991). Polskie zmory i niektóre wierzenia z nimi związane. Studia z Filologii Polskiej i Słowiańskiej, 27, 17-23.

Cherek, J. (1976). Zmora w ludowych wierzeniach Pomorza Wschodniego. W: Informator Muzeum Piśmiennictwa i Muzyki Kaszubsko-Pomorskiej (ss. 57-73). Wejherowo.

Cielo, A. (1917). Fortunes and dreams: A practical, manual of fortune telling, divination and the interpretation of dreams, sings and omens. New York: George Sully and Company.

Dancygier, B., \& Sweetser, E. (2014). Figurative language. Cambridge: University Printing House.

Delaney, G. (2000). Wszystko o snach (H. Pawlikowska-Gannon, Tłum.). Warszawa: Bertelsmann Media.

Długosz-Kurczabowa, K., \& Dubisz, S. (2006). Gramatyka historyczna języka polskiego. Warszawa: Wydawnictwo Uniwersytetu Warszawskiego.

Drozdowska, W. (1962). Istoty demoniczne w Załęczu Wielkim, powiat Wieluń. Łódzkie Studia Etnograficzne, 4, 117-130.

Dźwigoł, R. (2004). Polskie ludowe słownictwo mitologiczne. Kraków: Wydawnictwo Naukowe Akademii Pedagogicznej.

Freud, Z. (1982). Wstęp do psychoanalizy (S. Kempterówna \& W. Zaniewicki, Tłum.). Warszawa: Państwowe Wydawnictwo Naukowe.

Freud, Z. (2000). Psychopatologia życia codziennego. Marzenia senne (L. Jekels \& H. Ivanka, Tłum.). Warszawa: Wydawnictwo Naukowe PWN.

Freud, Z. (2010). O marzeniu sennym (B. Rank, Tłum.). Warszawa: Drukarnia Narodowa S. A.

Kant, I. (1900). Dreams of a spirit-seer. London: Swan Sonnenschein \& CO, LIM.

Kleszczowa, K. (1996). Słowotwórstwo języka doby staropolskiej: Przegląd formacji rzeczownikowych. Katowice: Wydawnictwo Uniwersytetu Śląskiego.

Kolberg, O. (1962). Wielkie Księstwo poznańskie (Cz. 7). Warszawa: Ludowa Spółdzielnia Wydawnicza.

Kowalewska, D. (2009). Magia i astrologia w literaturze polskiego oświecenia. Toruń: Wydawnictwo Naukowe Uniwersytetu Mikołaja Kopernika.

Krótki, Z. (2015). Przepowiednia w historii języka polskiego. Etnoligwistyka, 27, 167-184.

Niebrzegowska, S. (1996). Polski sennik ludowy. Lublin: Wydawnictwo UMSC.

Ostrowska, K. (2005). Jak interpretować sny. Białystok: Studia Antropopsychologii.

Potkatecki, S. (2011). Snow dobrych obronę a szkodliwych przestrogę z potrzebnymi naukami rodzajewi ludzkiemu. Kraków. W: S. Poklatecki, O snach i czarach (J. Korczak \& E. Madeyska, Przedruk i oprac.). Wrocław: Oficyna Wydawnicza ATUT - Wrocławskie Wydawnictwo Oświatowe. (Przedruk wyd. z 1595)

Syreński, S. (1613). Zielnik herbarzem z języka łacińskiego zowia to jest opisanie własne imion, kształtu, przyrodzenia, skutków, i mocy ziół wszelakich drzew krzewin y korzenia ich, 
kwiatu, owoców, soków miazg, żywic i korzenia do potraw zaprawowania także trunków, syropów, wódek lekiwarzów, konfektów [...] pilnie zebrane a porządnie zapisane przez D. Simona Syreniusa. Kraków: Drukarnia Bazylego Skalskiego.

\section{Słowniki}

Bańko, M., Bobrowski, I., Karpiński, A., Karpluk, M., Puzynina, J., Rzepka, W. R., \& Siekarska, K. (Red.). (1999-2014). Elektroniczny słownik XVII i pierwszej połowy XVIII wieku [SXVII]. Pobrano 10 października 2015, z http://sxvii.pl/

Bańkowski, A. (2000). Etymologiczny słownik języka polskiego [SBań]. Warszawa: Wydawnictwo Naukowe PWN.

Boryś, W. (2005). Słownik etymologiczny języka polskiego [SBor]. Kraków: Wydawnictwo Literackie.

Brückner, A. (1927). Słownik etymologiczny języka polskiego [SBr]. Warszawa: Krakowska Spółka Wydawnicza.

Doroszewski, W. (Red.). (1958-1969). Słownik języka polskiego [SD]. Warszawa: PWN.

Dubisz, S. (2003). Uniwersalny słownik języka polskiego [USJP]. Warszawa: Wydawnictwo Naukowe: PWN.

Linde, B. S. (1807-1814). Słownik języka polskiego [SL]. Warszawa.

Mayenowa, M. R. (Red.). (1966). Słownik polszczyzny XVI wielu [SXVI]. Wrocław - Warszawa Kraków: Ossolineum.

Urbańczyk, S. (Red.). (1966-2000). Słownik staropolski [SStp]. Warszawa - Wrocław - Kraków: IJP PAN.

Zdanowicz, A., \& Bohusz-Szyszka, M. (Red.). (1861). Słownik języka polskiego [SWil]. Wilno.

\section{Names of dreams in the history of the Polish language}

\section{Summary}

This article analyzes old names of dreams. During the process of collecting and sorting of the material, etymological data were taken into consideration, which allowed to establish that all the investigated units concentrated around three fields: 1 . words with the root: sen/sn-, 2. words with the root: mor-/mar-/ marz-, 3. words with the root: widz-. 
The dominating method in this sketch is the analysis of contexts in which the words within the "dream field" appeared. Considering as evidence the usages of each word recorded in dictionaries of old Polish, I deduce its meaning value in particular periods.

\title{
Nazwy marzeń sennych w historii języka polskiego
}

\author{
Streszczenie
}

W artykule analizie poddano dawne nazwy marzeń sennych. Podczas porządkowania materiału pod uwagę wzięto dane etymologiczne, które pozwoliły ustalić, że wszystkie badane jednostki koncentrowały się wokół trzech pól: 1. o rdzeniu sen-/śn-; 2. o rdzeniu mor-/mar-/marz-; 3. o rdzeniu widz-.

Metodą dominującą w szkicu jest analiza kontekstów, w których występowały wyrazy należące do pola marzenie senne. Na podstawie poświadczeń użycia danego wyrazu w słownikach rejestrujących polszczyznę dawną wnioskuję o jego wartości znaczeniowej w danym okresie.

Keywords: nomination; semantics; history of the Polish language; meaning change

Słowa kluczowe: nominacja; semantyka; historia języka polskiego; zmiany znaczeniowe

Zuzanna Krótki, Katowice

Correspondence: zuzanna_krotki@interia.pl

This article was prepared at the author's own expense.

Competing interests: The author has declared she has no competing interests. 